\title{
IN VITRO ANTICANCER ACTIVITY OF NANAZOXID DRUG AGAINST COLORECTAL CANCER CELL LINE AND ITS MOCLECULAR PATHWAYS
}

\author{
Nourhan.M.Abed ${ }^{1}$, Salwa.M.El-hallouty ${ }^{2 *}$, Emad.M.El-zayat ${ }^{3}$ and Ahmed.Abdou.Elsherief $^{4}$ \\ 1- MSc student at Department of Biotechnology, Faculty of Science, Cairo University, Cairo, Egypt. \\ 2- Drug Bioassay-Cell Culture Laboratory, Pharmacognosy Department, National Research Center, Dokki, Giza, \\ 12622, Egypt. \\ 3- Department of Zoology, Faculty of Science, Cairo University, Cairo, Egypt. \\ 4- Department of Chemistry, Faculty of Science, Cairo University, Cairo, Egypt. \\ *Corresponding author's E-mail: $\underline{\text { Hallouty68@gmail.com }}$
}

Submitted August 3, 2021; Accepted October 11, 2021; Published November 21, 2021

\section{SUMMARY}

Drug repurposing is gaining popularity in treatment discovery because it is a smart strategy to quickly exploit new molecular targets of a known clinically authorized drug in a variety of diseases, both existing and novel. Some early studies showed that hydroxychloroquine which has long been used for malaria, is used to reduce fever and inflammation of COVID-19 patients. Cancer is a major health issue worldwide. During the past years, some drugs are proved to be anticancer drugs as Raloxifene to treat breast cancer and Aspirin to treat colorectal cancer.

According to the national cancer institute the second most killer cancer is the cancer of colon and rectum around the world. Colorectal cancer is Egypt's seventh most prevalent cancer, accounting for $3.47 \%$ cancers. Colon cancer patients (excluding rectal cancer) were expected to number somewhat more than 3,000. Our aim in this project is to repurpose clinically used antibiotics in the Egyptian market for colorectal cancer. Anticancer efficacy of numerous antibiotic drugs was being tested by screening them in monolayer (2D).Results showed that Nanazoxid as a promising drug as anti-cancer drug especially for colorectal cancer with IC50 (0.20 $\mu \mathrm{g} / \mathrm{ml}$ ) and was tested for its selectivity index on human cell line and was subjected to molecular analysis.

As a result, an antibiotic drug which is Nanazoxid proved that it could be repurposed as an anti-colorectal therapy with proper further research and development.

Keywords: Colorectal Cancer- Drug Repurposing- -Antibiotics- human cell line-Aspirin- COVID-19-Nanazoxid

\section{INTRODUCTION}

The process of discovering new biological targets for existing drugs that have already been approved for the treatment of other diseases or whose targets have already been discovered is known as drug repurposing. This method is not time-consuming, costly, or financially risky. (Padhy and Gupta. 2011)Also, it is able to be relevant on recognized and uncommon illnesses as Covid-19 that's A novel coronavirus (CoV) named 'COVID-19' with the aid of using the World Health Organization (WHO) is in price of the modern outbreak of pneumonia that commenced at the start of December 2019 close to in Wuhan City, Hubei Province, China (Hui et al,.2020) and the time is so restricted to discover a new technique to deal with COVID-19 however drug repurposing that's the quicker manner helped to locate powerful healing dealers because the antiviral and antimalarial sremdesivir, favipiravir, ribavirin, lopinavir-ritonavir combination, arbidol, tocilizumab, chloroquine and hydroxychloroquine(Singh et al.,2020).

Cancer is a main cause loss of life and morbidity across the world. According to current World Health Organization estimates every year most cancers prevalence in Sub-Saharan Africa is 551 200, with 421 000 deaths in line with year (2008) Low- and middleprofits international locations accounted for nearly $70 \%$ of all most cancers fatalities (El-Hallouty et al.,2015)

Colorectal cancer is the world's third most frequent cancer and the fourth leading cause of death, accounting for more than $9 \%$ of all cancer cases. It has equal risk in both sexes where males have a slightly higher risk for rectal cancer than females. Furthermore, colorectal cancer affects roughly 40/100,000 people in the United States, Australia, and Western Europe, compared to approximately5/100,000 in Africa and portions of Asia. (Haggar and Boushey, 2009).

Nanazoxid drug (nitazoxanide) is the treatment for Cryptosporidium infections (Gargala ,2008) In Africa and Asia, Cryptosporidium infection is the second cause of severe diarrhea in young children (Kotloff et al.,2013) and in this study we discovered the high cytotoxic effect of nanazoxid on colorectal cancer cell line HCT-116 with $\mathrm{IC}_{50} 0.20 \mu \mathrm{g} / \mathrm{ml}$ and selectivity index 125.41 . 
Nanazoxid possess antiproliferative activity according to the flowcytometry results as the cell growth arrest at G1/S phase and induces apoptosis of HCT116 cellsby upregulatingBax- P53 -Casp3 genes and downregulating the $\mathrm{BCL}-2$ gene.

\section{MATERIALS AND METHODS}

Antibiotics:

Table 1.The antibiotic drugs used in the research were obtained from the Egyptian market

\begin{tabular}{ll}
\hline Drug & Company \\
\hline Nanazoxid & Utopia pharmaceutical \\
Benzabiotic & Sedico pharmaceutical \\
Quinabiotic & Utopia pharmaceutical \\
Floxamo & amoun pharm.co \\
Tavanic & sanofiwinthropindustrie \\
Respenzo & hochster \\
Augmentin & GlaxoWellcome \\
Rovac & delta \\
Ceporex & GLAXO \\
Omnicef & Al-Hikma Pharmaceuticals \\
\hline
\end{tabular}

\section{Cancer cell lines:}

In this study, the human colon carcinoma cell line (HCT-116), and a skin normal human cell line (BJ-1) immortalized normal foreskin fibroblast cell line. These cell lines were obtained from Karolinska Institute, Department of Oncology and Pathology (Stockholm, Sweden).

\section{Molecularanalysis:}

RN easy extraction kit (Qiage , Hilden, Germany), Super Script ${ }^{\mathrm{TM}}$ II Reverse Transcriptase (Biorad, USA),iScript One-Step RT-PCR Kit with SYBR® Green (Biorad, USA), Forward and reverse primers of target genes (Sigma, USA). Annexin V-FITC Apoptosis Detection kit: (BioVision, USA) A.Cytotoxicity bioassay on HCT116 and BJ-1 monolayers.

\section{Cell culture:}

HCT116 human colon carcinoma cell line and skin normal human cell line (BJ-1) were maintained in DMEM: F12 Medium/10\% FBS. Both cell lines were incubated at $37^{\circ} \mathrm{C}$ in $5 \% \mathrm{CO} 2$ and $95 \%$ humidity. Cells were sub-cultured using trypsin versene $0.15 \%$.

\section{MTT assay:}

After $24 \mathrm{hrs}$ of seeding 10,000 HCT-116 cellsper welland 50,000 BJ-1 cells per well (in 96-well plates), a100-ppmfinal concentration of the tested drugs were added in triplicates. The cells were treated for $120 \mathrm{hrs}$. $1 \mu \mathrm{M}$ Doxorubicin was used as positive control and $0.5 \%$ DMSO was used as a negative control. Cytotoxicity was determined using MTT [3-(4, 5dimethylthiazol-2-yl)-2,5-diphenyltetrazolium bromide] assay as described by Mosmann in1983 (Mosmann, 1983).Cytotoxicity was calculated according to the following equation: $[1-(\operatorname{av}(x)) /(\operatorname{av}$
(NC))]*100. Where: Av: average, X: absorbance of sample, NC: absorbance of negative control. Absorbance was measured at $595 \mathrm{~nm}$ with reference $690 \mathrm{~nm}$.

Determination of $\mathrm{IC}_{50}$ values:

In case of highly active drugs possessing $\geq 70 \%$ cytotoxicity on colorectal cancer cell line.Different concentrations were prepared for dose response studies. The results were used tocalculate the $\mathrm{IC}_{50}$ values of each drug using probit analysis and utilizing the SPSS computer program (SPSSfor windows, statistical analysis software package / version 9 / 1989 SPSS Inc., Chicago, USA).

\section{Selectivity Index (SI):}

The selectivity index (SI) indicates the cytotoxic selectivity (i.e. safety) of the drug against colorectal cancer cell versus normal cells (BJ-1, skin human normal immortalized cell line). $\mathrm{SI}=\mathrm{IC}_{50}$ of promising drug in a normal cell line/ $\mathrm{IC}_{50}$ of the same promising drug in cancer cell line. (Prayonget al., 2008)

\section{B. RNA isolation:}

The effect of the drug (Nanazoxid) on the mRNA expression of the Bcl-2, P53, Caspase-3 and Bax was determined by a reverse transcription-polymerase chain reaction (RT-PCR) technique. After the treatment (48 h) [12] of the HCT116 cells with the extract, RNA was extracted from the cells using the RNeasy extraction kit (Qiagen, Hilden, Germany) following the manufacturer's protocol. Concisely, up to $1 \times 106$ of the cultured cells were trypsinized, washed with PBS, and collected in an RNase-free centrifuge tube. The sample was then centrifuged at $300 \times \mathrm{g}$ for $5 \mathrm{~min}$, and the supernatant was aspirated off. The pellet was disrupted and homogenized in RLT buffer (buffer RLT 
is a lysis buffer for lysing cells and tissues before RNA isolation and simultaneous RNA/DNA/protein isolation).

The homogenized lysate was then transferred into a $2 \mathrm{ml}$ collection tube, and $1 \mathrm{ml}$ of $70 \%$ ethanol was added to the lysate and mixed with pipetting. Then, 700 $\mu \mathrm{l}$ of the sample was transferred into an RNeasy spin column placed in a $2 \mathrm{ml}$ collection tube and centrifuged at $10,000 \mathrm{rpm}$ for $15 \mathrm{sec}$. The flow-through was discarded and $700 \mu$ of the RW1 buffer (buffer RW1 is a proprietary component of RNeasy kits. Buffer RW1 contains a guanidine salt, as well as ethanol, and is used as a stringent washing buffer that efficiently removes biomolecules such as carbohydrates, proteins, and fatty acids) was added to the spin column and centrifuged at $10,000 \mathrm{rpm}$ for $15 \mathrm{~s}$.

The previous step was repeated 2 times using $500 \mu \mathrm{l}$ of the RPE buffer (buffer RPE is a mild washing buffer and a proprietary component of RNeasy kits. Its main function is to remove traces of salts, which are still on the column due to buffers used earlier in the protocol) instead of the RW1 buffer to wash the spin column membrane. The collection tube was discarded, and a new $1.5 \mathrm{ml}$ tube was used instead, $40 \mu \mathrm{l}$ of RNase-free water was added to the center of the membrane and centrifuged at 10,000 rpm for $1 \mathrm{~min}$. The spin column was discarded as the collection tube contains the eluted RNA.

\section{Gene expression analysis:}

After the RNA extraction, one-step RT-qPCR was performed using iScript ${ }^{\mathrm{TM}}$ One-Step RT-PCR kit with SYBR® Green (Bio-Rad Inc., CA, USA) which was added to the Master Mix which contained $25 \mu \mathrm{l} 2 \mathrm{x}$ SYBR Green ${ }^{\circledR}, 1.5 \mu \mathrm{l}$ forward primer $(10 \mu \mathrm{M}), 1.5 \mu \mathrm{l}$ reverse primer $(10 \mu \mathrm{M}), 11 \mu \mathrm{l}$ nuclease-free water, and $1 \mu \mathrm{l} \times 50$ iScript Reverse Transcriptase in a final reaction volume of $50 \mu \mathrm{l}$. Two control reactions were created; one lacking the RNA template and the other lacking the reverse transcriptase enzyme.

The one-step RT-qPCR reaction included an incubation step with the complete reaction mix, iScript Reverse Transcriptase enzyme inactivation step, qPCR step (denaturation, annealing, and extension), and dissociation step. The amplification reactions were carried out using the Rotor-Gene Q Real-Time PCR system (Qiagen, Hilden, Germany).

The primers' sequences used to quantify the gene expression of the of Bcl-2, P53, Caspase-3, Baxand $\beta$ Actin as housekeeping genes are:

$\begin{array}{llll}\text { Caspase-3 gene } 3 \text { is } & \text { F: } & 5^{\prime}- \\ \text { TGTTGTGTGCTTCTGAGCC-3'and } & \text { R: } & 5^{\prime}- \\ \text { CACGCCATGTCATCATCAAC-3'. } & & \end{array}$
CACGCCATGTCATCATCAAC-3'.

Bax gene is F: 5'-ATGTTTTCTGACGGCAACTTC3'and R: 5'-AGTCCAATGTCCAGCCCAT-3'.

$\begin{aligned} & \text {-Actin gene is } \\ & \text { GTGACATCCACACCCAGAGG-3, and R: }\end{aligned}$, $5^{\prime}$ -
ACAGGATGTCAAAACTGCCC-3'.

Bcl-2 gene is F: 5'-ATGTGTGTGGAGACCGTCAA3' and R: 5'GCCGTACAGTTCCACAAAGG-3'.

P53 gene is F: 5'-ATGTTTTGCCAACTGGCCAAG3' and R: 5'TGAGCAGCGCTCATGGTG-3'.

\section{Flow cytometry:}

For the measurement of the cellular DNA content, flow cytometric analysis was carried out using the Annexin V-FITC Apoptosis Detection kit (BioVision, CA, USA). After $48 \mathrm{~h}$ of treatment, HCT116 cells were trypsinized and washed with serum-containing media. The solution was then centrifuged at $300 \times \mathrm{g}$ for $10 \mathrm{~min}$, the supernatant was decanted, and the pellet was resuspended in $500 \mu \mathrm{l}$ of $\times 1$ binding buffer. Then, $5 \mu \mathrm{l}$ of Annexin V-FITC and $5 \mu$ of propidium iodide were incubated with the cells for $5 \mathrm{~min}$ in the dark. The sample was quantified by BD FACSCalibur (BD Bioscience, CA, USA

\section{Results}

\section{A. Cytotoxicity bioassay on HCT116 monolayers:}

Data were pooled from the MTT assays where 10 antibiotic drugs were tested on HCT-116lines (100 ppm) the results showed after screening of antibiotics, all are below $70 \%$ for the cytotoxicity effect. Only one drug is promising which is Nanazoxid has more than $70 \%$ cytotoxicity effect. So it's the only drug was prepared in different concentration ranges from 100 ppm to $0.048 \mathrm{ppm}$ then the determination of IC50 in comparison with normal cell line (BJ-1) 

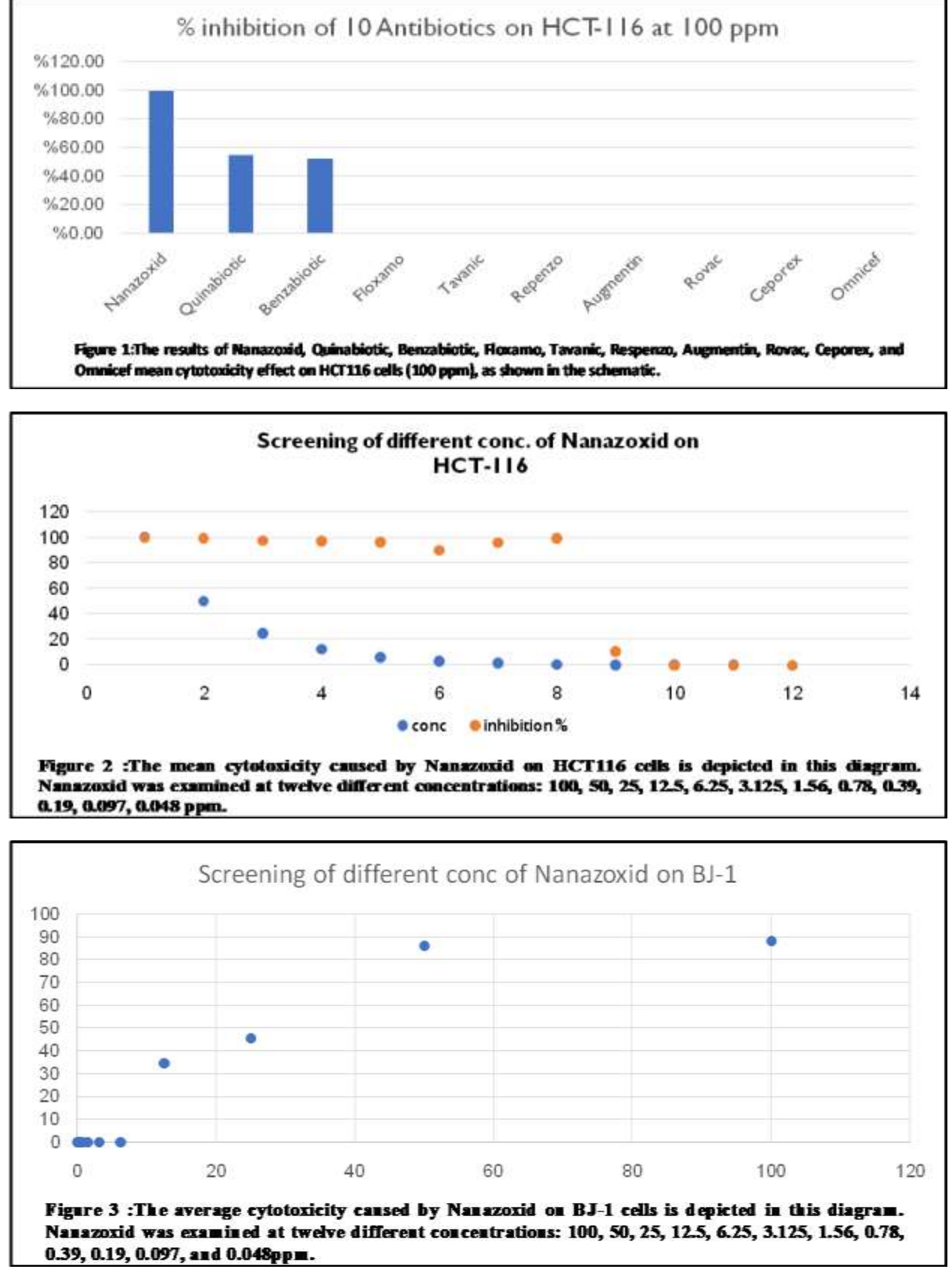
Egyptian-Arab J. Applied Sci. and Tech. (EAJAST) (2021)

The inhibition concentration (IC50) of Nanazoxid on HCT-116 and BJ-1 are represented below (Table 2 and Table 3)

Table 2. IC50 value on the HCT116 cell line

\begin{tabular}{cc}
\hline Drug & IC50 \\
\hline Nanazoxid & $0.20 \mu \mathrm{g} / \mathrm{ml}$ \\
\hline
\end{tabular}

Table 3. IC50 value on the BJ-1 cell line

\begin{tabular}{cc}
\hline Drug & IC50 \\
\hline Nanazoxid & $25.082 \mu \mathrm{g} / \mathrm{ml}$ \\
\hline Selectivity
\end{tabular}

Selectivity index $=25.082 / 0.20=125.41$.

B. Gene Expression analysis:

By evaluating the amount of expression of Caspase3, Bax, P53, and Bcl-2 genes in HCT-116 cells, the influence of IC50 $(0.20 \mu \mathrm{g} / \mathrm{ml}$ for HCT116) Nanazoxid on gene regulation was examined using qRT-PCR. Gene expression changes were computed using the 2$\Delta \Delta \mathrm{Ct}$ method and are shown as fold changes.

Equation: $2 \Delta \Delta \mathrm{Ct}=2 \mathrm{Ct}$ (treated cells)-Ct (control cells)

After comparing the expression levels of the Caspase-3, Bax, P53, and Bcl-2 genes in treated and untreated cells, it was discovered that the Bcl-2 gene to be slightly down by 0.169 folds, the Bax gene was over expressed by 10.72 folds, P53 was down expressed by 6.52 folds, and Casp3 was down expressed by 7.57 folds. Changes in the expression levels of the respective genes in HCT116 are depicted (Table 4 and Figure 4).Because it is a highly conserved gene that is often employed as an internal control for gene expression research, the $\beta$-actin gene was chosen as an internal control "Housekeeping gene." (Roh et al., 2000)

Table 4. Effects of Nanazoxidon Caspase-3, Bax, p53 and Bcl-2 gene expressions in HCT116 cellline

\begin{tabular}{cc}
\hline Genes & Change in Expression (Folds) \\
\hline Caspase-3 & 7.57 \\
Bax & 10.72 \\
p53 & 6.52 \\
Bcl-2 & 0.169 \\
\hline
\end{tabular}

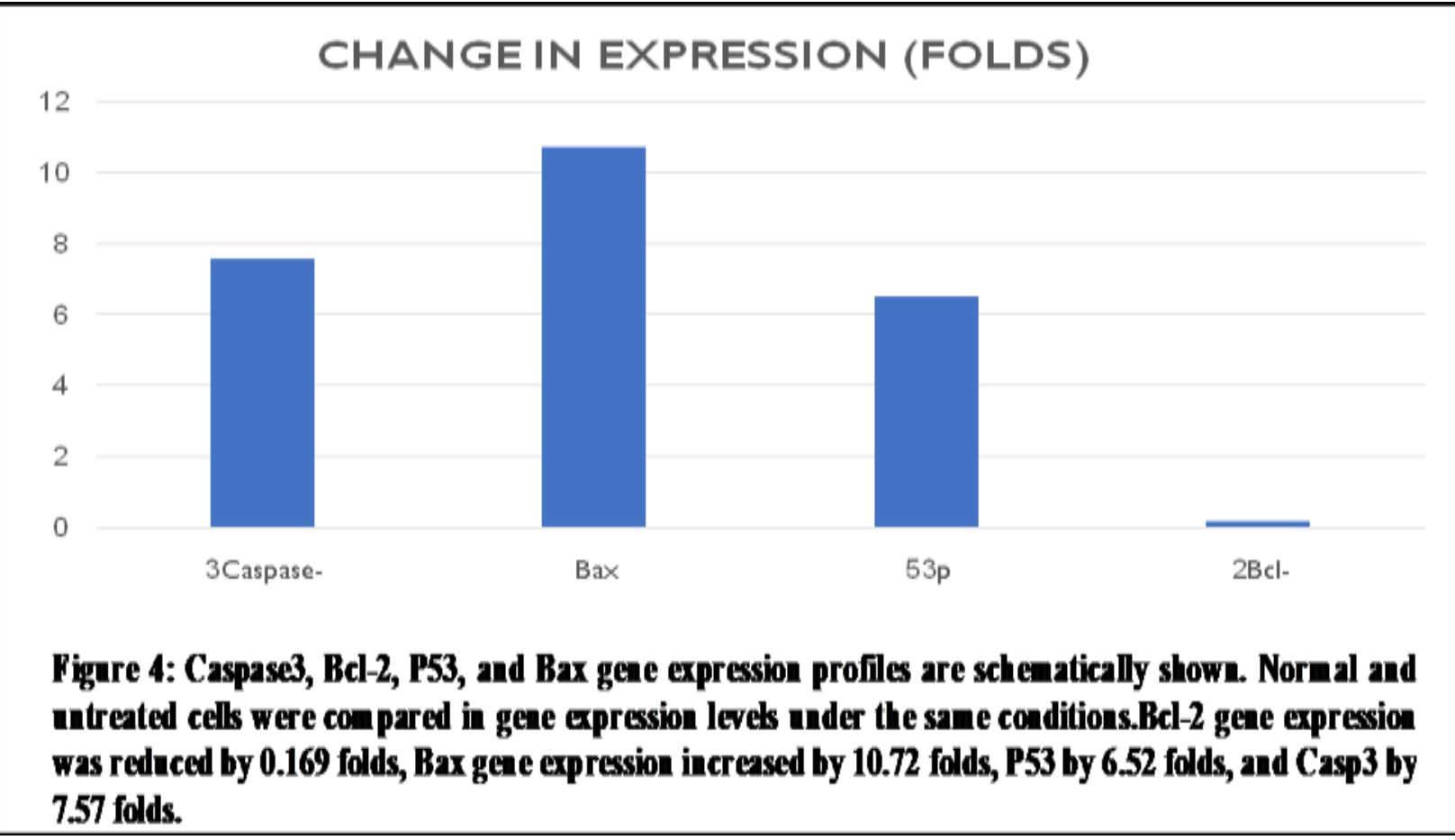




\section{Nourhan.M.Abed et al.}

C. Apoptosis induced by Nanazoxid observed using Flowcytometry:

1. After the HCT116 cells were treated with Nanazoxid, there was a cell growth arrest at $\mathrm{G}_{0}-\mathrm{G}_{1}$ phase and $S$ phase. An increase in Pre $G_{1}, G_{0}-G_{1}$ and decrease in $G_{2}-M$ and slightly increase in $S$ phase (Table 5 and Figure 5)

Table 5. After a 24-hour treatment with Nanazoxid, the cell cycle in HCT116 cells was examined

\begin{tabular}{|c|c|c|c|c|}
\hline Sample data & \multicolumn{4}{|c|}{ Results DNA content } \\
\hline IC50 ug/ml & \% G0-G1 & $\% \mathrm{~S}$ & \%G2/M & \%Pre-G1 \\
\hline Treated & 51.23 & 45.28 & 3.49 & 47.31 \\
\hline Control & 48.04 & 42.61 & 9.35 & 1.69 \\
\hline
\end{tabular}
60
50
40
30
20
10
0

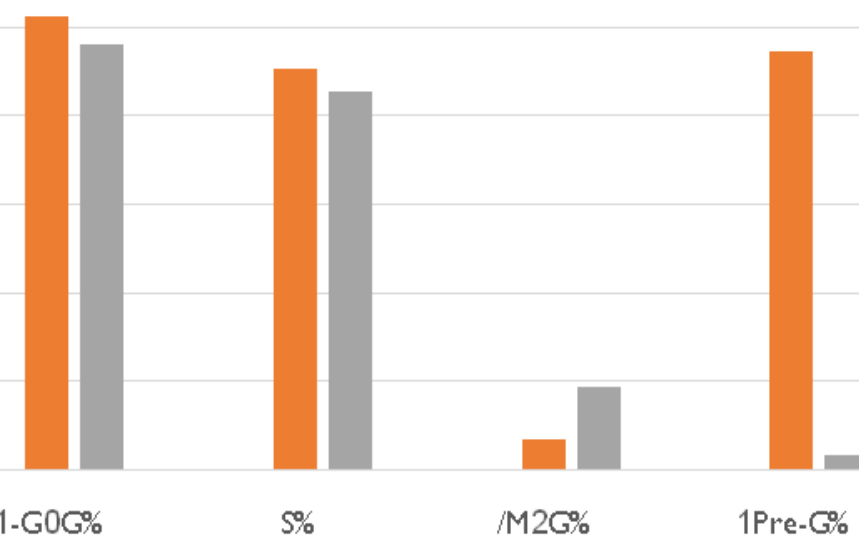
- code $\quad$ Treated $\quad$ Control

\begin{abstract}
Figure 5:The cell cyde profiles of the treated and control HCT116 cells are depicted schematically. In the G0-G1 and S phases, the proportion of cells grew, fell in the G2-M phase, and increased in the pre-G1 phase.
\end{abstract}

2. When a cell enters apoptosis, the apoptosis marker phosphatidylserine is exposed to the plasma membrane's surface. To evaluate Nanazoxid's apoptotic capacity in HCT116 cells, Annexin V, a Ca2+dependent phospholipid-binding protein with an affinity for PS, is used to identify this signal. According to the flowcytometry, the drug triggered $1.86 \%$ early, $27.44 \%$ late apoptosis and $18.01 \%$ necrosis (Table 6 and Figure 6).

Table 6. Apoptotic effects of Nanazoxidon the HCT116 cells

\begin{tabular}{lccccc}
\hline \multicolumn{5}{c}{ Apoptosis } & \\
\hline code & conc & Total & Early & Late & Necrosis \\
\hline Treated & 47.31 & 1.86 & 27.44 & 18.01 \\
Control & 1.69 & 0.46 & 0.14 & 1.09 \\
\hline
\end{tabular}




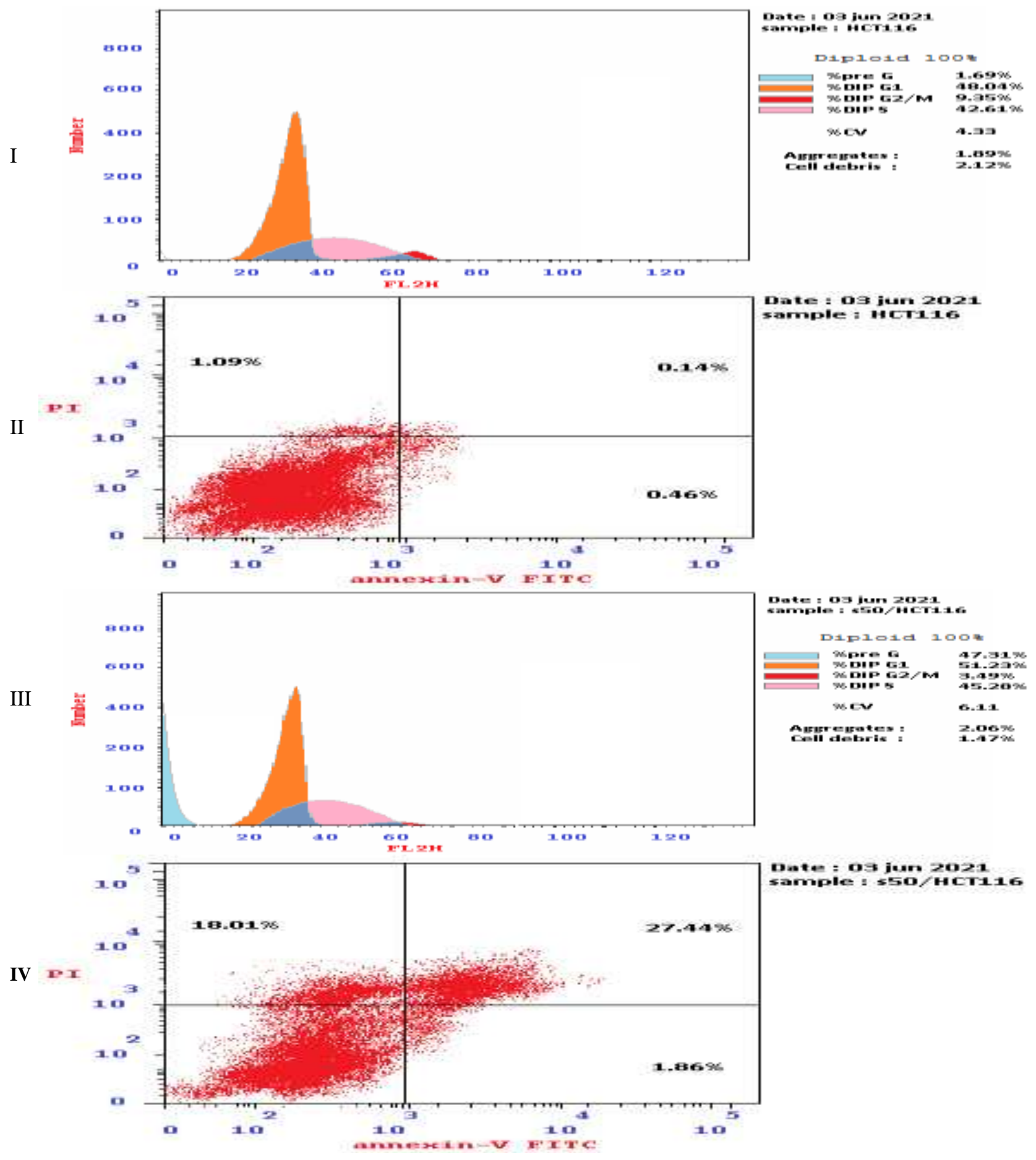

Figure 6: Nanazoxid's apoptotic activity on the HCT116 cell lines is depicted schematically. I. represents the cell count at various stages of the cell cycle (untreated control); II represents the cell count at various stages of the cell cycle (treated with $4 \mathrm{~g} / \mathrm{ml}$ of Nanazoxid for $48 \mathrm{~h}$ ); III Annexin V/PI (untreated control); Annexin V/PI (treated with $4 \mathrm{~g} / \mathrm{ml}$ of Nanazoxid for $48 \mathrm{~h}$ ); IV Annexin V/PI (treated with $4 \mathrm{~g} / \mathrm{ml}$ of Nanazoxid for 48)

\section{DISCUSSION}

Different antibiotics were tested in this research to see if they had anticancer action against a colorectal cancer cell line. One of the 10 drugs has anti- proliferative properties. The antibiotics with the most promising inhibitory effect were chosen for additional testing in order to figure out how these effects work. 


\section{Nourhan.M.Abed et al.}

On HCT-116 cancer cell line, benzobiotic and quinabiotic had mild anticancer effects.

Nanazoxid had a high level of cytotoxicity in the HCT-116 cell line (IC50 of $0.20 \mu \mathrm{g} / \mathrm{ml}$ ), but only had a little effect on normal BJ-1 cells. This means Nanazoxid is only cytotoxic to colorectal cancer cells.

The distribution of cells in the cell cycle was changed by Nanazoxid, according to the cell cycle analysis. The proportion of cells in the G0-G1 and S phases increased, while the number of cells in the G2$M$ phase reduced and the pre-G1 phase grew slightly. These findings point to a disruption in the cell cycle, with the cell trapped in the G0-G1 and S phases.

Nanazoxid produced $1.86 \%$ early apoptosis and $27.44 \%$ late apoptosis, according to flow cytometry data (Table 6). Furthermore, it caused necrosis in 18.01 $\%$ of the treated cells against $1.09 \%$ of untreated cells. Nanazoxid had a great potential to induce apoptosis. Induction of necrosis is also somewhat elevated. As a result, the drug is being examined as a potential anticancer medication.

The treatment of HCT-116 cells with Nanazoxid resulted in a shift in the anti-apoptotic/pro-apoptotic balance of the cells toward undergoing apoptosis, demonstrating that the drug can shift the cells' antiapoptotic/pro-apoptotic balance toward undergoing apoptosis (Table 6).

The analysis indicates that there was a very little down expression in the Bcl-2 gene by 0.169 folds in the treated and untreated cells, overexpression in the Bax gene by 10.72 folds, P53 by 6.52 folds, and Casp3 by 7.57 folds in the treated cells.(Table 4).Nanazoxid was shown to have a strong potential to trigger apoptosis by downregulating $\mathrm{Bcl} 2$ genes and boosting the overexpression of pro-apoptotic proteins like Bax and apoptotic proteins like P53 and Casp3, making it a prospective anticancer drug.

\section{CONCLUSION}

Nanazoxid has a strong influence on cell proliferation and apoptosis, and it has been shown that it affects the cell cycle and gene expression of Casp3, Bax, P53, and Bcl-2. However, more research into the molecular mechanism that controls the balance between cellular growth and death is needed.Nanazoxid's ability to generate high cytotoxicity in a colorectal cancer cell line in vitro. Because of its great anticancer activity, it should be explored further to see if it may be utilized as a treatment for colorectal cancer. Benzobiotic and Quinabiotic can also be studied further because they have a mild anticancer impact.

\section{REFRENCES}

El-Hallouty, S.M., Fayad, W., Meky, N.H., ElMenshawi, B.S., Wassel, G.M., and Hasabo,
A.A. 2015. Int.J. PharmTech Res. 8(2): 267272 .

Gargala, G. 2008. Drug treatment and novel drug target against Cryptosporidium. Parasite. 15: 275-81

Greenlee, R.T., Hill-Harmon, M.B., Murray, T., and Thun, M. 2001. Cancer statistics, 2001. CA.Cancer. J. Clin. 51: 15-36

Haggar, F.A., and Boushey, R.P. 2009.Colorectal Cancer Epidemiology: Incidence, Mortality, Survival, and Risk Factors. Clinics in Colon and Rectal Surgery. 22: 191-197

Hui D.S., Azhar. E., Madani, T.A., Ntoumi, F., Kock, R., Dar. O., Ippolito, G., Mchugh, T.D., Memish, Z.A., Drosten, C., Zumla, A., Petersen, E. 2020. The continuing 2019-nCoV epidemic threat of novel coronaviruses to global health - The latest 2019 novel coronavirus outbreak in Wuhan, China. Int J Infect Dis. 91: 264-266.

Kotloff ,K.L., Nataro, J.P., Blackwelder, W.C., Nasrin, D., Farag, T,H., Panchalingam, S., Wu, Y., Sow, S.O., Sur, D., Breiman, R.F., Faruque ,A.S., Zaid,I, A.K., Saha D, Alonso, P.L, Tamboura B, Sanogo D, Onwuchekwa U, Manna B, Ramamurthy T, Kanungo S, Ochieng, J.B, Omore R, Oundo ,J.O, Hossain A, Das, S,K, Ahmed S, Qureshi S, Quadri F, Adegbola ,R.A, Antonio M, Hossain, M.J, Akinsola A, Mandomando I, Nhampossa T, Acácio S, Biswas K, O'Reilly ,C.E, Mintz ,E.D, Berkeley ,L.Y, Muhsen K, Sommerfelt H, Robins-Browne ,R.M., Levine ,M.M. 2013. Burden and aetiology of diarrhoeal disease in infants and young children in developing countries (the Global Enteric Multicenter Study, GEMS): a prospective, case-control study. Lancet. 382(9888): 209-22

Mosmann, T. 1983. Rapid colorimetric assay for cellular growth and survival: application to proliferation and cytotoxicity assays. J. Immunol Methods. 65(1-2): 55-63

Padhy, B.M and Gupta, Y.K, 2011.Drug repositioning: re-investigating existing drugs for new therapeutic indications. J Postgrad Med. 57(2): 153-60.

Prayong, P., Barusrux, S., Weerapreeyakul. N. 2008. Cytotoxic activity screening of some indigenous Thai plants. Fitoterapia. 79(7): 598-601.

Roh, H., Pippin, J., Drebin, J.A. 2000. Down-regulation of HER2/neu expression induces apoptosis in human cancer. 60(3): 560-5.

Singh, T.U., Parida, S., Lingraju, M.C., Kesavan, M., Kumar, D., Singh, R.K. 2020.Durg repurposing approach to fight covid19. Pharmacological Reports. 72(6): 14. 
Egyptian-Arab J. Applied Sci. and Tech. (EAJAST) (2021)

\author{
الملخص العربى \\ نشاط عقار نانازوكسيد كمضاد للسرطان في المختبر ضد خلايا سرطان القولون والمستقيم ومساراته الجزيئية

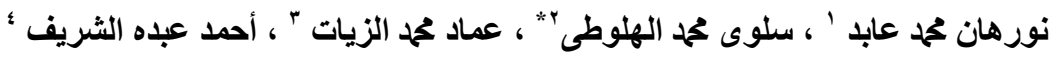 \\ ا ـ طالب ماجستير في قسم البيوتكنولوجى ، كلية العلوم ، جامعة القاهزة ، القاهزة ، مصر.

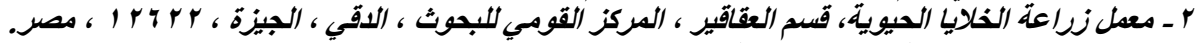

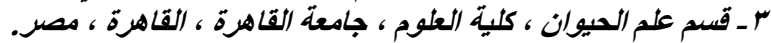

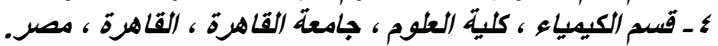

تكتسب إعادة توظيف الأدوية شعبية في اكتثاف العلاج لأنها استر اتيجية ذكية للاستفادة بسر عة من أهداف جزيئية جديدة لعقار مرخص سريرئًا

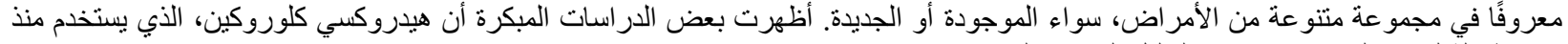

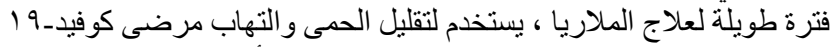

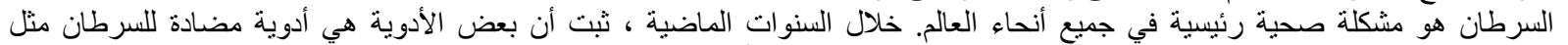

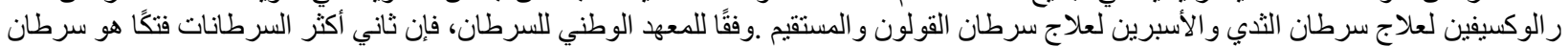

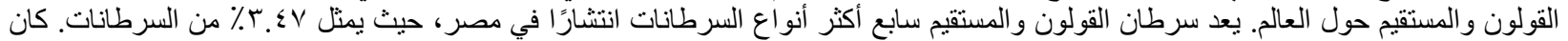

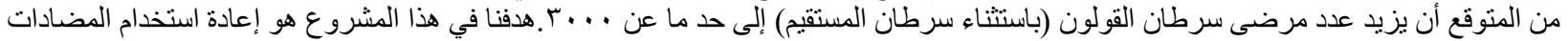

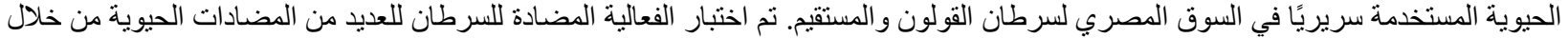

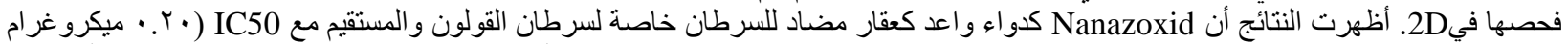

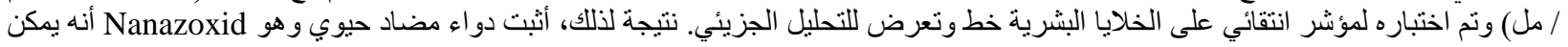

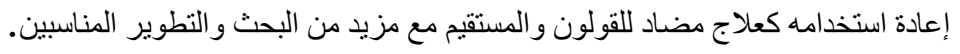

الكلمات الدفتاحية: سرطان القولون والمستقيم - إعادة استخد/م الأدوية ـ المضادات الحيوية ـ خط الذلايا البشرية ـ الأسبرين ـ كوفيل 9 ـ ـ 